\title{
Influence of methionine supply on the response of lactational performance of dairy cows to supplementary folic acid and vitamin $B_{12}{ }^{1}$
}

\author{
A. Preynat, ${ }^{\dagger} \dagger$ H. Lapierre, ${ }^{*}$ M. C. Thivierge,$\dagger^{2}$ M. F. Palin, ${ }^{*}$ J. J. Matte, ${ }^{*}$ A. Desrochers, $\ddagger$ and C. L. Girard ${ }^{* 3}$ \\ *Agriculture et Agroalimentaire Canada, Centre de Recherche et Développement sur le Bovin Laitier et le Porc, Sherbrooke, Québec, \\ J1M 1Z3, Canada \\ †Département de Sciences Animales, Université Laval, Québec, G1V 0A6, Canada \\ ‡Faculté de Médecine Vétérinaire, Université de Montréal, St-Hyacinthe, Québec, J2S 7C6, Canada
}

\section{ABSTRACT}

The present experiment was undertaken to determine if the effects of supplementary folic acid on lactational performance were caused by improved methylneogenesis and if the supply in vitamin $\mathrm{B}_{12}$ could affect this metabolic pathway. In this eventuality, supplementary Met, a major source of preformed methyl groups, should reduce the requirements for these vitamins. Sixty multiparous Holstein cows were assigned to 10 blocks of 6 cows each according to their previous milk production. Within each block, 3 cows were fed a diet estimated to supply Met as $1.83 \%$ metabolizable protein and 3 cows were fed the same diet supplemented with $18 \mathrm{~g}$ of rumen-protected methionine (RPM) to supply Met as $2.23 \%$ of metabolizable protein. Within each level of Met, cows received no vitamin supplement or weekly intramuscular injections of $160 \mathrm{mg}$ of folic acid alone or combined with $10 \mathrm{mg}$ of vitamin $\mathrm{B}_{12}$ from 3 wk before to 16 wk after calving. There was no treatment effect on dry matter intake during pre- and postcalving periods: $13.4 \pm 0.4$ and $21.8 \pm 0.4 \mathrm{~kg} / \mathrm{d}$, respectively. Milk production was not affected by RPM supplementation. Folic acid and vitamin $\mathrm{B}_{12}$ given together tended to increase milk production during the 16 wk of lactation. This effect was more pronounced during the first $4 \mathrm{wk}$ of lactation: $37.5,37.7$, and $40.3 \pm 0.9 \mathrm{~kg} / \mathrm{d}$ for cows receiving no vitamin supplement, folic acid alone, or folic acid combined with vitamin $\mathrm{B}_{12}$, respectively. Milk fat yield was not affected by treatments. Lactose, crude protein, and total solid yields were greater, in early lactation, in cows injected with folic acid and vitamin $\mathrm{B}_{12}$ together but this effect diminished as lactation progressed. Intramuscular injections of folic acid alone or combined with vitamin $\mathrm{B}_{12}$ tended to decrease plasma

Received July 23, 2008.

Accepted December 16, 2008.

${ }^{1}$ Contribution no. 982.

${ }^{2}$ Current address: Obesity and Metabolic Health Division, Rowett Research Institute, Aberdeen, United Kingdom, AB21 9SB.

${ }^{3}$ Corresponding author: Christiane.Girard@agr.gc.ca concentrations of homocysteine from $5.51 \mu M$ with no vitamin supplement to 4.54 and $4.77 \pm 0.37 \mu M$, respectively. Results of the present experiment suggest that the effects of the combined supplement of folic acid and vitamin $\mathrm{B}_{12}$ on lactational performance of dairy cows were not due to an improvement in methyl groups supply, because RPM supplement, a source of preformed methyl groups, did not alter the cow responsiveness to vitamin supplements.

Key words: dairy cow, folic acid, vitamin $\mathrm{B}_{12}$, rumenprotected methionine

\section{INTRODUCTION}

Previous experiments (see review, Girard and Matte, 2005a), showed that supplementary folic acid could increase milk and milk protein yields in dairy cows but responses to the vitamin supplement were variable. The unique role of folic acid is the transfer of 1-carbon units and it is essential to 2 metabolic pathways: DNA synthesis and the methylation cycle. Tetrahydrofolate (THF) accepts 1-carbon units from donors such as Ser, Gly, His, or formate and transfers them for purine and pyrimidine synthesis for DNA synthesis. Reactions in this pathway are reversible. Tetrahydrofolate, after being reversibly converted to 5,10-methylene-THF could also become involved in the methylation cycle after its irreversible conversion to 5-methyl-THF. The major function of the methylation cycle is to provide Sadenosylmethionine (SAM), which is the major donor of methyl groups in mammals. After having given its methyl group, SAM becomes S-adenosylhomocysteine and then homocysteine (Hcy). Homocysteine, a nonstructural AA, could be catabolized through the transsulfuration pathway or remethylated to Met. Remethylation of Hcy uses 5-methyl-THF as a source of de novo methyl groups. This reaction is mediated by an enzyme, methionine synthase, for which vitamin $\mathrm{B}_{12}$ is a coenzyme (Lucock, 2000). As the production of 5-methyl-THF is irreversible and because this form of folates cannot be retained in the cells, deficiency of 
vitamin $\mathrm{B}_{12}$ can trap folic acid under its methylated form, 5-methyl-THF, and reduces its cellular utilization (Scott and Weir, 1981; Bässler, 1997).

A parenteral supplement of vitamin $B_{12}$ given to cows fed a basal diet supplemented with folic acid and Met increased milk component yields compared with cows supplemented only with Met and folic acid (Girard and Matte, 2005b). However, in cows fed a diet providing a low Met supply, dietary supplements of folic acid given alone or in combination with vitamin $\mathrm{B}_{12}$ increased milk and milk protein yields (Graulet et al., 2007). It is noteworthy that in this latter study the 2 vitamins given together seem to improve metabolic efficiency by increasing plasma glucose and decreasing accumulation of hepatic lipids compared with folic acid alone (Graulet et al., 2007). However, the mode of action of supplementary folic acid is fully not elucidated.

Given the metabolic roles of folic acid, the effects of supplementary folic acid on lactational performance could be related to its action on DNA synthesis or the methylation cycle. Cellular concentration of SAM is a function of the availability of methyl groups, which are provided as preformed labile methyl groups by Met, betaine, and choline or by de novo synthesis from folate metabolism as described above. If the effects of supplementary folic acid on lactational performance of dairy cows are mediated through the methylation cycle, then supplementary Met, a major source of preformed methyl groups for SAM synthesis, should reduce the requirements for folic acid and vitamin $\mathrm{B}_{12}$. Therefore, given the importance of vitamin $\mathrm{B}_{12}$ to prevent functional deficiency of folates and the role of Met, as a source of methyl groups, the present experiment was undertaken to elucidate the metabolic pathways explaining the effects of supplementary folic acid on lactational performance described previously.

\section{MATERIALS AND METHODS}

\section{Cows and Treatments}

Sixty multiparous Holstein cows from the herd at the Agriculture and Agri-Food Canada Research Centre (Sherbrooke, Quebec, Canada) were kept in a tie-stall barn under $16 \mathrm{~h}$ of light per day (0630 to $2230 \mathrm{~h}$ ) and milked twice daily at 12 -h intervals. Care of cows followed the recommended code of practice of Agriculture Canada (1990) and the guidelines of the Canadian Council of Animal Care (1993). The experimental period began 3 wk before the expected time of calving and lasted until 16 wk after calving. Cows were fed a close-up diet for $3 \mathrm{wk}$ before the expected time of calving until calving and thereafter a basal lactation diet (Table 1). Cows had free access to water and were fed ad libitum allowing 10\% refusals. The TMR was served once daily before calving (at $0800 \mathrm{~h}$ ) and twice daily after calving (0800 and $1600 \mathrm{~h}$ ). Long hay was given at $0730 \mathrm{~h}$ during the entire experimental period. The amount of feed served was recorded every day, whereas refusals were weighed daily at $0700 \mathrm{~h}, 5 \mathrm{~d} /$ wk. Dry matter intake was calculated per week for each cow as follows: average amount of feed served per day $(7 \mathrm{~d} /$ wk) minus average amount of orts per day $(5 \mathrm{~d} / \mathrm{wk})$.

Cows were assigned to 10 blocks of 6 cows each according to their average milk production in the previous lactation $(27.8 \pm 0.5 \mathrm{~kg} / \mathrm{d})$. Treatments were tested according to a $2 \times 3$ factorial arrangement. Within each block, 3 cows were fed the basal diet estimated (NRC, 2001) to supply Met as $1.83 \%$ of MP supply (M-), whereas the 3 other cows were fed the same diet supplemented daily with rumen-protected Met (RPM; M+: 9 and 18 g of Mepron-85/d, Degussa AG, Hanau, Germany, pre- and postcalving respectively). With a net Met concentration of $85 \%$, rumen by-pass protection of $73 \%$, and intestinal digestibility of $82 \%$ (Berthiaume et al., 2001), the product used in the present experiment was estimated to provide $9.2 \mathrm{~g} / \mathrm{d}$ of Met after calving and to increase the estimated Met supply to $2.23 \%$ of MP (NRC, 2001). Within each level of Met (M+ or M-), cows received no vitamin supplement $\left(\mathbf{B}_{9}-\mathbf{B}_{12}-\right)$, or weekly intramuscular injections of $160 \mathrm{mg}$ of folic acid alone (pteroylmonoglutamic acid, ICN Biochemicals Inc., Cleveland, $\left.\mathrm{OH} ; \mathbf{B}_{9}+\mathbf{B}_{12}-\right)$ or in combination with $10 \mathrm{mg}$ of vitamin $\mathrm{B}_{12}$ (cyanocobalamin, $5,000 \mu \mathrm{g} / \mathrm{mL}$, Vetoquinol, Lavaltrie, Québec, Canada; $\mathbf{B}_{9}+\mathbf{B}_{12}+$ ). The amounts of vitamin supplemented were selected according to previous experiments (Girard et al., 1995; Girard and Matte, 2005b). The parenteral route was chosen, instead of dietary supplementation, to isolate the effects of vitamins on cow metabolism and to rule out any possible effect on ruminal microflora.

\section{Sampling Procedures}

Feed. Forage samples were collected twice a week. A subsample was immediately analyzed by near infrared reflectance spectrometry to adjust, when necessary, the amounts of energy and protein supplements to maintain similar concentrations of energy and degradable and undegradable proteins throughout the experimental period. Another subsample was frozen at $-20^{\circ} \mathrm{C}$ for further analyses: DM, CP, ash, ether extract (AOAC, 1990), ADF, NDF, and acid-detergent lignin (Ankom200 fiber analyzer, Ankom Technology Corp., Fairport, NY) and minerals by inductively coupled plasma emission spectrometry (Agri-Food Laboratories, Guelph, Ontario, Canada). 
Table 1. Ingredients and nutrient composition of the diets fed to dairy cows

\begin{tabular}{|c|c|c|}
\hline Item & Close-up diet & Lactation diet \\
\hline \multicolumn{3}{|l|}{ Ingredients, \% } \\
\hline Grass hay & $33.0^{1}$ & $8.2^{2}$ \\
\hline Legume-grass silage $^{3}$ & 11.0 & 23.4 \\
\hline Corn silage $^{4}$ & 14.5 & 23.1 \\
\hline Cracked corn & 16.9 & 28.5 \\
\hline Soybean meal, 49\% & & 9.6 \\
\hline Beet pulp & 13.3 & \\
\hline Micronized soybean & 3.9 & 2.0 \\
\hline Distillers grain (wheat) & 1.3 & 0.7 \\
\hline Distillers grain (corn) & 2.2 & 1.1 \\
\hline Canola meal & 1.3 & 0.7 \\
\hline Mineral and vitamin premix & $1.6^{5}$ & $1.8^{6}$ \\
\hline Calcium carbonate & 1.0 & 0.8 \\
\hline \multicolumn{3}{|l|}{ Nutrient composition } \\
\hline $\mathrm{CP}, \%$ & 12.8 & 17.3 \\
\hline $\mathrm{RDP}^{7} \%$ & 7.9 & 10.6 \\
\hline $\mathrm{RUP}^{7} \%$ & 4.9 & 6.7 \\
\hline $\mathrm{ADF}, \%$ & 26.5 & 19.2 \\
\hline NDF, \% & 45.2 & 30.4 \\
\hline $\mathrm{NE}_{\mathrm{L}}{ }^{8} \mathrm{Mcal} / \mathrm{kg}$ of DM & 1.55 & 1.58 \\
\hline $\mathrm{MP}^{8} \mathrm{~g} / \mathrm{d}$ & 1,055 & 2,341 \\
\hline Methionine, ${ }^{8} \%$ of MP & 1.85 & 1.83 \\
\hline Lysine, ${ }^{8} \%$ of MP & 6.18 & 6.3 \\
\hline $\mathrm{K}, \%$ & 1.27 & 1.55 \\
\hline $\mathrm{Ca}, \%$ & 0.69 & 0.87 \\
\hline $\mathrm{P}, \%$ & 0.52 & 0.44 \\
\hline $\mathrm{Mg}, \%$ & 0.39 & 0.29 \\
\hline S, $\%$ & 0.25 & 0.26 \\
\hline $\mathrm{Cl}, \%$ & 0.43 & 0.34 \\
\hline \multirow{4}{*}{\multicolumn{3}{|c|}{$\begin{array}{l}{ }^{1} 7.8 \pm 1.1 \% \mathrm{CP}, 0.8 \pm 0.1 \% \text { soluble protein, } 34.2 \pm 5.8 \% \mathrm{ADF}, 58.9 \pm 7.0 \% \mathrm{NDF}, 5.6 \pm 0.6 \% \text { lignin }(\mathrm{n}=3) . \\
{ }^{2} 10.9 \pm 1.7 \% \mathrm{CP}, 2.4 \pm 0.1 \% \text { soluble protein, } 31.9 \pm 1.8 \% \mathrm{ADF}, 55.1 \pm 4.2 \% \mathrm{NDF}, 4.4 \pm 0.5 \% \text { lignin }(\mathrm{n}= \\
5) . \\
{ }^{3} 16.8 \pm 2.3 \% \mathrm{CP}, 8.0 \pm 1.2 \% \text { soluble protein, } 32.8 \pm 4.1 \% \mathrm{ADF}, 42.3 \pm 5.9 \% \mathrm{NDF}, 7.5 \pm 2.5 \% \text { lignin }(\mathrm{n}= \\
11) . \\
{ }^{4} 7.6 \pm 0.4 \% \mathrm{CP}, 3.5 \pm 0.6 \% \text { soluble protein, } 21.3 \pm 1.5 \% \mathrm{ADF}, 37.0 \pm 1.9 \% \mathrm{NDF}, 2.1 \pm 0.3 \% \operatorname{lignin}(\mathrm{n}= \\
10) . \\
{ }^{5} \mathrm{Contains} \text { per kilogram: } 30 \mathrm{~g} \text { of Ca, } 120 \mathrm{~g} \text { of P, } 120 \mathrm{~g} \text { of } \mathrm{Mg}, 69 \mathrm{~g} \text { of Na, } 106 \mathrm{~g} \text { of Cl, } 15 \mathrm{~g} \text { of K, } 20 \mathrm{~g} \text { of S, } 4,343 \\
\text { mg of Fe, } 6,566 \mathrm{mg} \text { of Mn, } 6,465 \mathrm{mg} \text { of } \mathrm{Zn}, 1,616 \mathrm{mg} \text { of } \mathrm{Cu}, 202 \mathrm{mg} \text { of } \mathrm{I}, 121 \mathrm{mg} \text { of Co, } 40 \mathrm{mg} \text { of Se }(25 \% \text { organic } \\
\text { selenium), } 732,323 \mathrm{IU} \text { of vitamin A, } 247,475 \mathrm{IU} \text { of vitamin D and } 7,576 \mathrm{IU} \text { of vitamin } \mathrm{E} .\end{array}$}} \\
\hline & & \\
\hline & & \\
\hline & & \\
\hline \multicolumn{3}{|c|}{$\begin{array}{l}{ }^{6} \text { Contains per kilogram: } 95 \mathrm{~g} \mathrm{Ca}, 55 \mathrm{~g} \mathrm{P}, 55 \mathrm{~g} \mathrm{Mg}, 130 \mathrm{~g} \mathrm{Na}, 150 \mathrm{~g} \mathrm{Cl}, 14 \mathrm{~g} \mathrm{~K}, 21 \mathrm{~g} \mathrm{~S}, 2,745 \mathrm{mg} \mathrm{Fe}, 2,065 \mathrm{mg} \\
\mathrm{Mn}, 3,000 \mathrm{mg} \mathrm{Zn}, 495 \mathrm{mg} \mathrm{Cu}, 69 \mathrm{mg} \mathrm{I}, 33 \mathrm{mg} \mathrm{Co}, 20 \mathrm{mg} \text { Se ( } 25 \% \text { organic selenium), 501,859 IU vitamin A, } \\
65,000 \mathrm{IU} \text { vitamin D and 2,600 IU vitamin E. }\end{array}$} \\
\hline \multicolumn{3}{|c|}{${ }^{7}$ Calculated according to NRC (2001) model. } \\
\hline \multicolumn{3}{|c|}{$\begin{array}{l}{ }^{8} \text { Calculated according to NRC }(2001) \text { from average DMI of control cows }\left(\mathrm{M}-, \mathrm{B}_{9}-\mathrm{B}_{12}-\right) \text { during the close-up } \\
(12.6 \mathrm{~kg} / \mathrm{d}) \text { and lactation }(21.8 \mathrm{~kg} / \mathrm{d}) \text { periods. }\end{array}$} \\
\hline
\end{tabular}

$\boldsymbol{B} \boldsymbol{W}$. Body weight was recorded at $22 \pm 5 \mathrm{~d}$ precalving and $14 \pm 2,28 \pm 2,56 \pm 2,84 \pm 2$, and $112 \pm 2 \mathrm{~d}$ after calving.

Milk. Milk production was recorded at each milking. Milk samples were collected during 4 consecutive milkings at $13 \pm 2,27 \pm 2,55 \pm 2,83 \pm 2$, and $111 \pm 2$ d of lactation. Milk composition (fat, protein, lactose, and urea) was determined with near infrared reflectance spectroscopy method (Valacta, Sainte-Anne-deBellevue, QC, Canada).

Blood. After the distribution of the morning meal, blood samples were collected at $24 \pm 5 \mathrm{~d}$ precalving and $14 \pm 2,28 \pm 2,56 \pm 2,84 \pm 2$, and $112 \pm 2 \mathrm{~d}$ after calving by caudal venipuncture, using a Vacutainer system (Becton Dickinson, Franklin Lakes, NJ). Tubes containing EDTA were used for analyses of folates, vitamin $\mathrm{B}_{12}$, vitamin $\mathrm{B}_{6}$, biotin, $\mathrm{BHBA}$, and NEFA, whereas tubes with heparin were used for AA, glucose, and urea determinations. Blood was centrifuged for 20 min within $1 \mathrm{~h}$ after sampling at 1,854 $\times g$ and $4^{\circ} \mathrm{C}$. For amino acid analysis, $400 \mu \mathrm{L}$ of plasma was mixed with $400 \mu \mathrm{L}$ of Met sulfone $(0.4 \mathrm{~m} M$, internal standard, Sigma, Oakville, Ontario, Canada). Plasma was kept frozen at $-20^{\circ} \mathrm{C}$ until assayed. 


\section{Laboratory Analyses}

Folates and Vitamin $\boldsymbol{B}_{12}$. Folates and vitamin $\mathrm{B}_{12}$ were determined in duplicate by radioassay using a commercial kit designed for human plasma (Quantaphase folates II/vitamin $\mathrm{B}_{12}$, Bio-Rad Laboratories Canada Ltd, Mississauga, Ontario, Canada) as described for plasma folates and vitamin $\mathrm{B}_{12}$ by Girard and Matte (1988), milk folates by Girard and Matte (1998), and milk vitamin $B_{12}$ by Preynat et al. (2009). The interassay coefficients of variation were 4.2 and $4.8 \%$ for folates and 4.1 and $6.3 \%$ for vitamin $\mathrm{B}_{12}$ in plasma and milk, respectively.

Plasma Biotin and Vitamin $\boldsymbol{B}_{6}$. Biotin was determined using an ELISA test developed and validated for bovine plasma (Santschi et al., 2005). Plasma vitamin $\mathrm{B}_{6}$ was determined by a fluorimetric method adapted by Matte et al. (1997) from Srivastava and Beutler (1973) and Petidier et al. (1986).

Plasma Urea, NEFA, Glucose, and BHBA. Plasma urea, NEFA, glucose and BHBA were determined using commercial kits: Diagnostic Chemicals Limited UREA ASSAY (BioPacific Diagnostic Inc., Charlottetown, Prince Edward Island, Canada); NEFAC (Wako Chemicals GmbH, Neuss, Germany); glucose (Roche Diagnostics GmbH, Mannheim, Germany); and $\beta$-hydroxybutyrate reagent set, (Pointe Scientific Inc., Canton, MI).

Total Hcy, Total Cys, Met, and other AA in Plasma. Total Hcy, total Cys and Met concentrations were determined in plasma by a modification of the HPLC method of Malinow et al. (1989) described in Girard et al. (2005). Further changes are reported in Preynat et al. (2009). Plasma concentrations of the other AA were determined by HPLC as described by Preynat et al. (2009).

\section{Statistical Analyses}

Two levels of Met supplementation (0 or $18 \mathrm{~g}$ of RPM) and 3 supplements of $\mathrm{B}$ vitamins (none, folic acid alone, or both folic acid and vitamin $\mathrm{B}_{12}$ ) were used in a $2 \times 3$ factorial arrangement in a 10 randomized complete block design. All variables were analyzed using the MIXED procedure (SAS Institute, 2004) according to a complete block design with treatments as main effects, repeated measures in time and block as random effect. Because the time intervals were different, the following covariance structures were compared: SP(POW), SP(GAU), SP(EXP), SP(LIN), SP(LINL), and $\mathrm{SP}(\mathrm{SPH})$. For each variable, the statistical analysis retained was the one with the smallest fit statistic values. Results are reported as least squares means and standard errors of the means. Means were assumed to

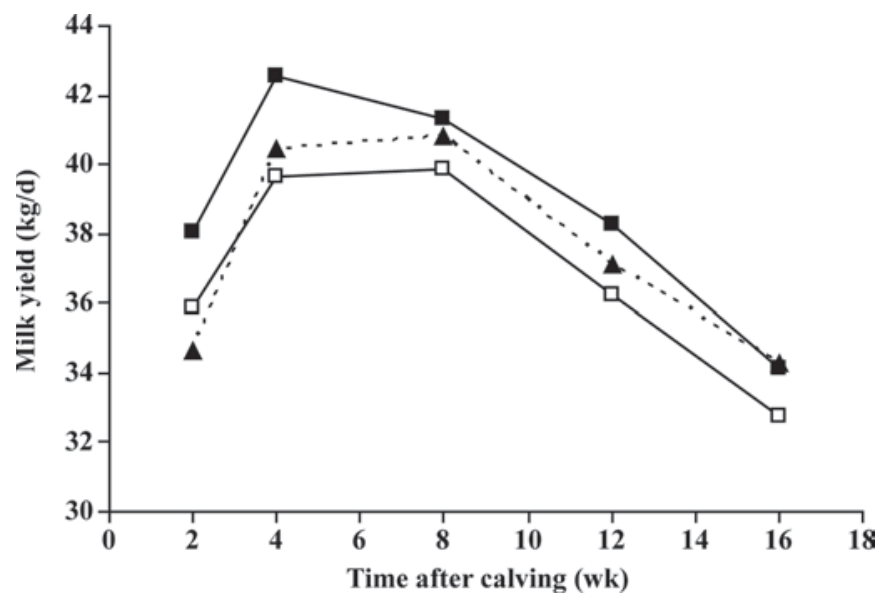

Figure 1. Effects of intramuscular injections of folic acid $\left(\mathrm{B}_{9}\right)$ and vitamin $B_{12}\left(B_{12}\right)$ given to dairy cows from 3 wk before calving to 16 wk of lactation on milk production. Values are averages of the 2 levels of Met supply. $\mathrm{B}_{9}-\mathrm{B}_{12}-\left(--\boldsymbol{\Lambda}^{--}\right)=$no vitamin supplement; $\mathrm{B}_{9}+\mathrm{B}_{12}-$ $(-\square-)=160 \mathrm{mg}$ of folic acid/wk; $\mathrm{B}_{9}+\mathrm{B}_{12}+(--)=160 \mathrm{mg}$ of folic acid $/ \mathrm{wk}+10 \mathrm{mg}$ of vitamin $\mathrm{B}_{12} / \mathrm{wk}(\mathrm{SEM}=1.0$; vitamin $\times$ time interaction, $P=0.10$ ).

be different at $P \leq 0.05$ and tended to differ at 0.05 $<P \leq 0.10$. When the vitamin effect reached a level of significance of $90 \%$, differences between means were compared using an adjusted Tukey test. When the Met $\times$ vitamin interaction reached a level of significance of $90 \%$, the SLICE option in the LSMEANS statement was used to help interpretation (SAS Institute, 2004).

\section{RESULTS}

\section{Lactational Performance}

At the beginning of the experiment, $3 \mathrm{wk}$ before the expected time of calving, BW was similar among treatments (702 $\pm 7 ; P \geq 0.7$; Table 2). However, during lactation, $\mathrm{BW}$ of $\mathrm{M}+$ cows decreased slightly more from wk 2 to 4 of lactation than for $\mathrm{M}$ - cows with 623 , $609,609,623$, and $620 \pm 9 \mathrm{~kg}$ versus $626,620,620,624$, and $626 \pm 9 \mathrm{~kg}$ at $2,4,8,12$, and 16 wk of lactation, respectively (Met $\times$ time interaction, $P=0.05$ ).

There was no treatment effect on DMI during the pre- and postcalving periods: DMI averaged $13.4 \pm 0.4$ and $21.8 \pm 0.4 \mathrm{~kg} / \mathrm{d}$, respectively $(P \geq 0.13$; Table 2$)$.

Milk production was not affected by RPM $(P=0.8$; Table 2). Folic acid and vitamin $B_{12}$ supplied together tended to increase milk production (vitamin, $P=0.08$, Table 2; and vitamin $\times$ time interaction, $P=0.10$, Figure 1). On average, during the 16 wk of lactation, milk production of $\mathrm{B}_{9}+\mathrm{B}_{12}+$ cows was 1.4 and $2 \mathrm{~kg} / \mathrm{d}$ higher than for $\mathrm{B}_{9}-\mathrm{B}_{12}-(P=0.12)$ and $\mathrm{B}_{9}+\mathrm{B}_{12}-(P$ $=0.03)$ cows, respectively. Average milk productions of $\mathrm{B}_{9}-\mathrm{B}_{12}-$ and $\mathrm{B}_{9}+\mathrm{B}_{12}-$ cows were not different $(P$ 
$=0.5)$. The response in milk production for $\mathrm{B}_{9}+\mathrm{B}_{12}+$ cows was more marked during the first 4 wk of lactation when milk production averaged 37.5, 37.7, and $40.3 \pm 0.9 \mathrm{~kg} / \mathrm{d}$ for $\mathrm{B}_{9}-\mathrm{B}_{12}-, \mathrm{B}_{9}+\mathrm{B}_{12}-$, and $\mathrm{B}_{9}+\mathrm{B}_{12}+$, respectively $(P=0.04)$. Gross efficiency (milk yield/ DMI) was affected differently by vitamin supplements according to Met supply (Met $\times$ vitamin interaction, $P$ $=0.01$; Table 2). Globally, in $\mathrm{M}-$ cows, although gross efficiency of $\mathrm{B}_{9}+\mathrm{B}_{12}-$ cows was numerically lower, there was no statistically significant effect of vitamin supplementation $(P=0.73)$. However, in $\mathrm{M}+$ cows, gross efficiency was higher for $\mathrm{B}_{9}+\mathrm{B}_{12}+$ than for $\mathrm{B}_{9}-\mathrm{B}_{12}-(P$ $=0.01)$ and $\mathrm{B}_{9}+\mathrm{B}_{12}-(P=0.0001)$; moreover, it was lower $(P=0.03)$ for $\mathrm{B}_{9}+\mathrm{B}_{12}-$ than for $\mathrm{B}_{9}-\mathrm{B}_{12}-$.

Milk fat and total solids concentrations did not differ among treatments $(P \geq 0.2$; Table 2$)$. Supplementation with RPM increased milk CP concentrations from 29.4 to $30.5 \pm 0.3 \mathrm{~g} / \mathrm{kg}$ for $\mathrm{M}-$ and $\mathrm{M}+$, respectively ( $P$ $=0.001$; Table 2). Response of lactose concentrations to vitamin supplements differed according to Met sup- ply $($ Met $\times$ vitamin interaction, $P=0.01$; Table 2$)$; there was no effect of B-vitamin supply in $\mathrm{M}-\operatorname{cows}(P$ $=0.66)$ but it changed milk concentrations of lactose in $\mathrm{M}+$ cows $(P=0.0001)$. In $\mathrm{M}+$ cows, milk lactose concentrations were similar $(P=0.86)$ for $\mathrm{B}_{9}-\mathrm{B}_{12}-$ and $\mathrm{B}_{9}+\mathrm{B}_{12}-$ cows, but lower for $\mathrm{B}_{9}+\mathrm{B}_{12}+$ cows $(P=$ $0.001)$.

Milk fat yield was not affected by treatments $(P$ $\geq 0.2$; Table 2). Milk yields of lactose, CP, and total solids were greater in early lactation in cows injected with folic acid and vitamin $\mathrm{B}_{12}$ together but this effect diminished as lactation progressed (vitamin $\times$ time interaction, $P \leq 0.05$; Figure 2).

Milk concentrations of urea tended to be altered by vitamin supplements $(P=0.10$; Table 2$)$, being higher for $\mathrm{B}_{9}+\mathrm{B}_{12}+$ cows than for cows receiving no vitamin supplement $(P=0.04)$ or folic acid alone $(P=0.002)$; $12.3,12.1$, and $12.9 \pm 0.3 \mathrm{mg} / \mathrm{dL}$ for $\mathrm{B}_{9}-\mathrm{B}_{12}-, \mathrm{B}_{9}+\mathrm{B}_{12}-$, and $\mathrm{B}_{9}+\mathrm{B}_{12}+$, respectively. Milk urea also tended to change during the first 16 wk of lactation according

Table 2. Effects of dietary supplements of rumen-protected Met $(M)$ and intramuscular injections of folic acid $\left(B_{9}\right)$ and vitamin $B_{12}\left(B_{12}\right)$ given to dairy cows from 3 wk before calving to 16 wk of lactation on DMI, milk production, and milk composition

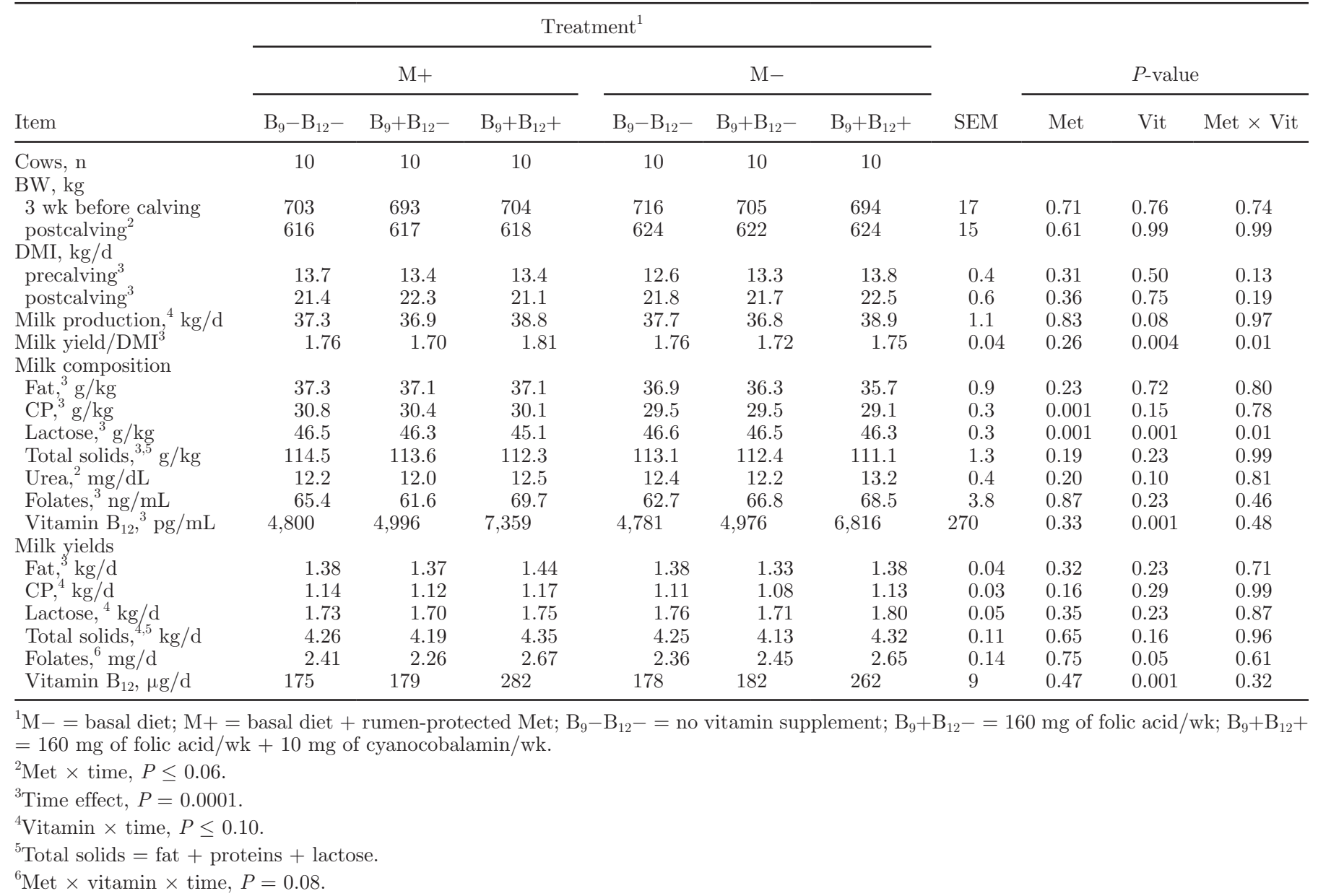




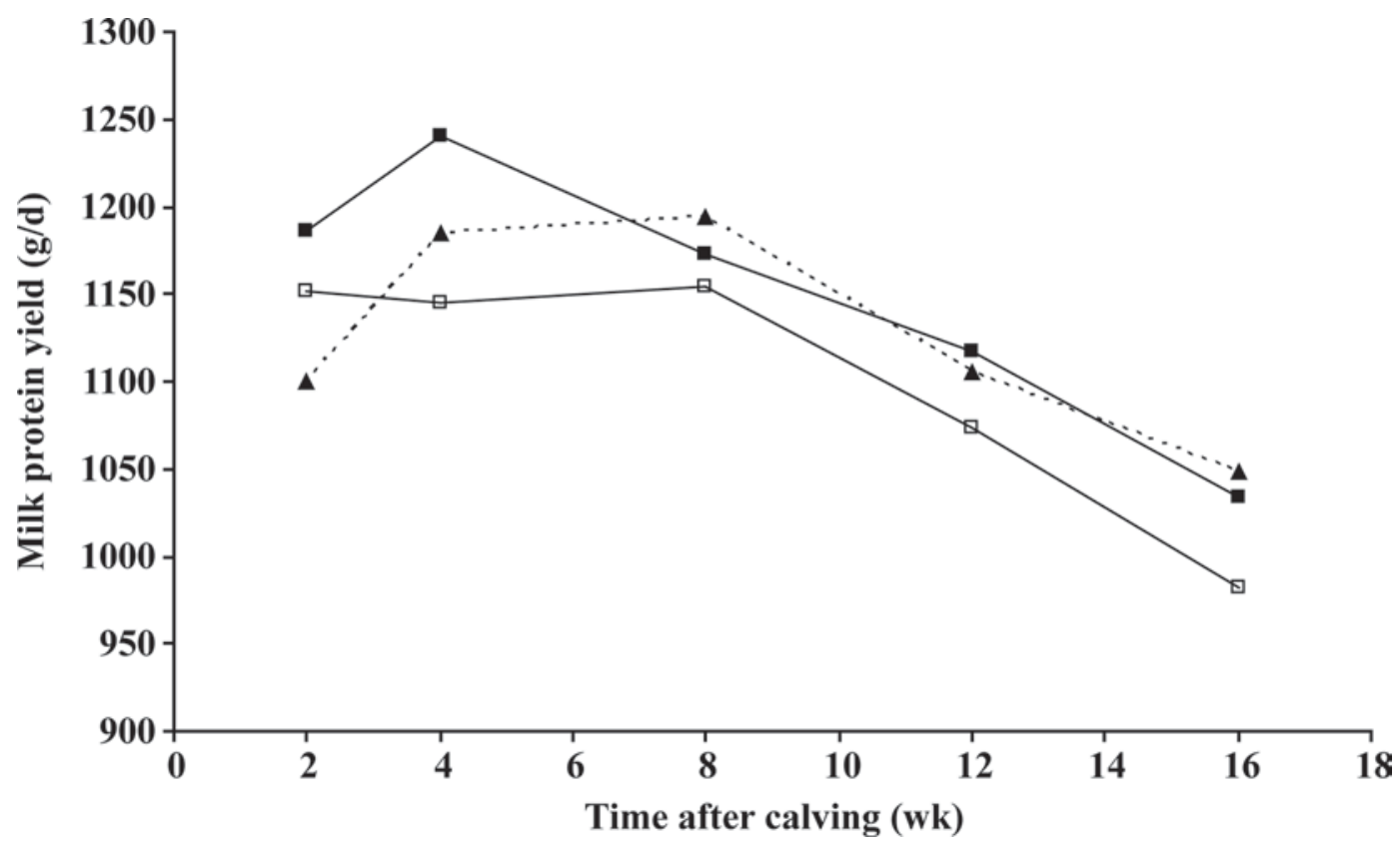

Figure 2. Effects of intramuscular injections of folic acid $\left(\mathrm{B}_{9}\right)$ and vitamin $\mathrm{B}_{12}\left(\mathrm{~B}_{12}\right)$ given to dairy cows from 3 wk before calving to 16 wk of lactation on milk protein yields. Values are averages of the 2 levels of Met supply. $\mathrm{B}_{9}-\mathrm{B}_{12}-\left(-\boldsymbol{\Lambda}^{--}\right)=$no vitamin supplement; $\mathrm{B}_{9}+\mathrm{B}_{12}-$ $(-\square-)=160 \mathrm{mg}$ of folic acid/wk; $\mathrm{B}_{9}+\mathrm{B}_{12}+(-\square-)=160 \mathrm{mg}$ of folic acid/wk $+10 \mathrm{mg}$ of vitamin $\mathrm{B}_{12} /$ wk $(\mathrm{SEM}=33.1$; vitamin $\times$ time interaction, $P=0.04)$.

to Met supplementation (Met $\times$ time interaction, $P=$ $0.06)$. At $2,4,8,12$, and 16 wk of lactation, milk urea concentrations averaged $11.9,12.3,12.8,13.3$, and 12.8 for $\mathrm{M}-$ and $12.4,12.0,11.3,12.8$, and $12.7 \pm 0.4 \mathrm{mg} /$ $\mathrm{dL}$ for $\mathrm{M}+$ cows, respectively.

There was no effect of vitamin supplements on average milk concentrations of folates during the first 16 wk of lactation $(P>0.2$; Table 2$)$. However, the amount of folates secreted in milk daily increased with the combined supplements of folic acid and vitamin $\mathrm{B}_{12}$ compared with the other treatments $(P \leq 0.05)$, averaging $2.38,2.36$, and $2.67 \pm 0.11 \mathrm{mg} / \mathrm{d}$ for $\mathrm{B}_{9}-\mathrm{B}_{12}-$, $\mathrm{B}_{9}+\mathrm{B}_{12}-$, and $\mathrm{B}_{9}+\mathrm{B}_{12}+$, respectively. Concentrations and amounts of vitamin $\mathrm{B}_{12}$ secreted in milk were increased by intramuscular injections of vitamin $\mathrm{B}_{12}(P$ $=0.001 ;$ Table 2 ).

\section{Plasma Variables}

$\boldsymbol{B}$ Vitamins. At the beginning of the experiment, 3 wk before the expected time of calving, plasma folates $(7.4 \pm 0.6 \mathrm{ng} / \mathrm{mL})$ and vitamin $\mathrm{B}_{12}(231 \pm 10 \mathrm{pg} / \mathrm{mL})$ were similar among treatments $(P \geq 0.3)$. On average, after calving, cows fed RPM tended to have lower plasma concentrations of folates than did $\mathrm{M}-$ cows $(P$ $=0.09$; Table 3) with, 15.2 versus $16.6 \pm 0.7 \mathrm{ng} / \mathrm{mL}$ for $\mathrm{M}+$ and $\mathrm{M}-$, respectively. The effect of vitamin supplementation on plasma folates changed during lactation (vitamin $\times$ time interaction, $P=0.03$; Figure 3). Plasma concentrations of folates in $\mathrm{B}_{9}-\mathrm{B}_{12}-$ and $\mathrm{B}_{9}+\mathrm{B}_{12}+$ cows increased to reach a plateau at $4 \mathrm{wk}$ of lactation, whereas in $\mathrm{B}_{9}+\mathrm{B}_{12}-$ cows, plasma folates increased until 8 wk after calving and decreased thereafter to reach a plateau at 12 wk of lactation.

Plasma concentrations of vitamin $\mathrm{B}_{12}$ were increased by vitamin $\mathrm{B}_{12}$ supplements $(P=0.001$; Table 3$)$ : 189 , 187 , and $365 \pm 15 \mathrm{pg} / \mathrm{mL}$ for $\mathrm{B}_{9}-\mathrm{B}_{12}-, \mathrm{B}_{9}+\mathrm{B}_{12}-$, and $\mathrm{B}_{9}+\mathrm{B}_{12}+$, respectively. Nevertheless, Met supply tended to modify the response to vitamin supplementation (Met $\times$ vitamin interaction, $P=0.1$ ). In cows injected with folic acid and vitamin $B_{12}$ together, plasma concentrations of vitamin $\mathrm{B}_{12}$ were higher $(P=0.04)$ in $\mathrm{M}+$ than in $\mathrm{M}-$ cows, whereas there was no such effect in $\mathrm{B}_{9}-\mathrm{B}_{12}-(P=0.5)$ and $\mathrm{B}_{9}+\mathrm{B}_{12}-(P=0.3)$. Overall, the lowest plasma concentrations of vitamin $\mathrm{B}_{12}$ were observed 4 and 8 wk after calving but increased thereafter (time, $P=0.06$ ) with $259,219,218,262$, and $278 \pm 18 \mathrm{pg} / \mathrm{mL}$ at $2,4,8,12$, and 16 wk of lactation, respectively.

Plasma concentrations of biotin and vitamin $\mathrm{B}_{6}$ were not affected by treatments $(P \geq 0.3$; Table 3$)$ but, for the 2 vitamins, the lowest concentration was observed 2 wk after calving (time, $P \leq 0.001$ ). At $2,4,8,12$, and 16 wk of lactation, plasma concentrations of vitamin 
$\mathrm{B}_{6}$ and biotin were $177,186,184,188$, and $181 \pm 5 \mathrm{ng} /$ $\mathrm{mL}$ and $911,979,979,1,054$, and 1,052 $\pm 18 \mathrm{pg} / \mathrm{mL}$, respectively.

Glucose, NEFA, BHBA, and Urea. Dietary supplements of RPM decreased the plasma concentrations of glucose from 3.63 to $3.55 \pm 0.03 \mu M(P=0.05$; Table 3). The lowest concentration was observed $2 \mathrm{wk}$ after calving with $3.45,3.55,3.71,3.63$, and $3.61 \pm 0.04$ $\mu M$ at $2,4,8,12$, and 16 wk of lactation, respectively (time, $P=0.001$ ).

Plasma concentrations of NEFA decreased during the experimental period (time, $P=0.001$ ) with 757,549 , 326,192 , and $159 \pm 30 \mu M$ at $2,4,8,12$, and $16 \mathrm{wk}$ of lactation but did not differ among treatments $(P \geq$ 0.2 ).

The response of plasma concentrations of BHBA to vitamin supplements tended to differ according to Met supply (Met $\times$ vitamin interaction, $P=0.06$; Table 3 ); cows fed RPM had higher $(P=0.02)$ BHBA concentrations than did $\mathrm{M}-$ cows when not supplemented with vitamins, whereas there was no effect $(P \geq 0.3)$ of Met supply on plasma BHBA in $\mathrm{B}_{9}+\mathrm{B}_{12}-$ and $\mathrm{B}_{9}+\mathrm{B}_{12}+$ cows. Plasma concentrations of BHBA decreased as lactation progressed (time, $P=0.02$ ) from $0.70,0.70$, $0.61,0.57$, and $0.52 \pm 0.04 \mathrm{mM}$ at $2,4,8,12$, and 16 wk of lactation, respectively.

Table 3. Effects of dietary supplements of rumen-protected Met $(M)$ and intramuscular injections of folic acid $\left(B_{9}\right)$ and vitamin $B_{12}\left(B_{12}\right)$ given to dairy cows from 3 wk before calving to 16 wk of lactation on plasma concentrations of some B-vitamins, glucose, urea, NEFA, BHBA and AA

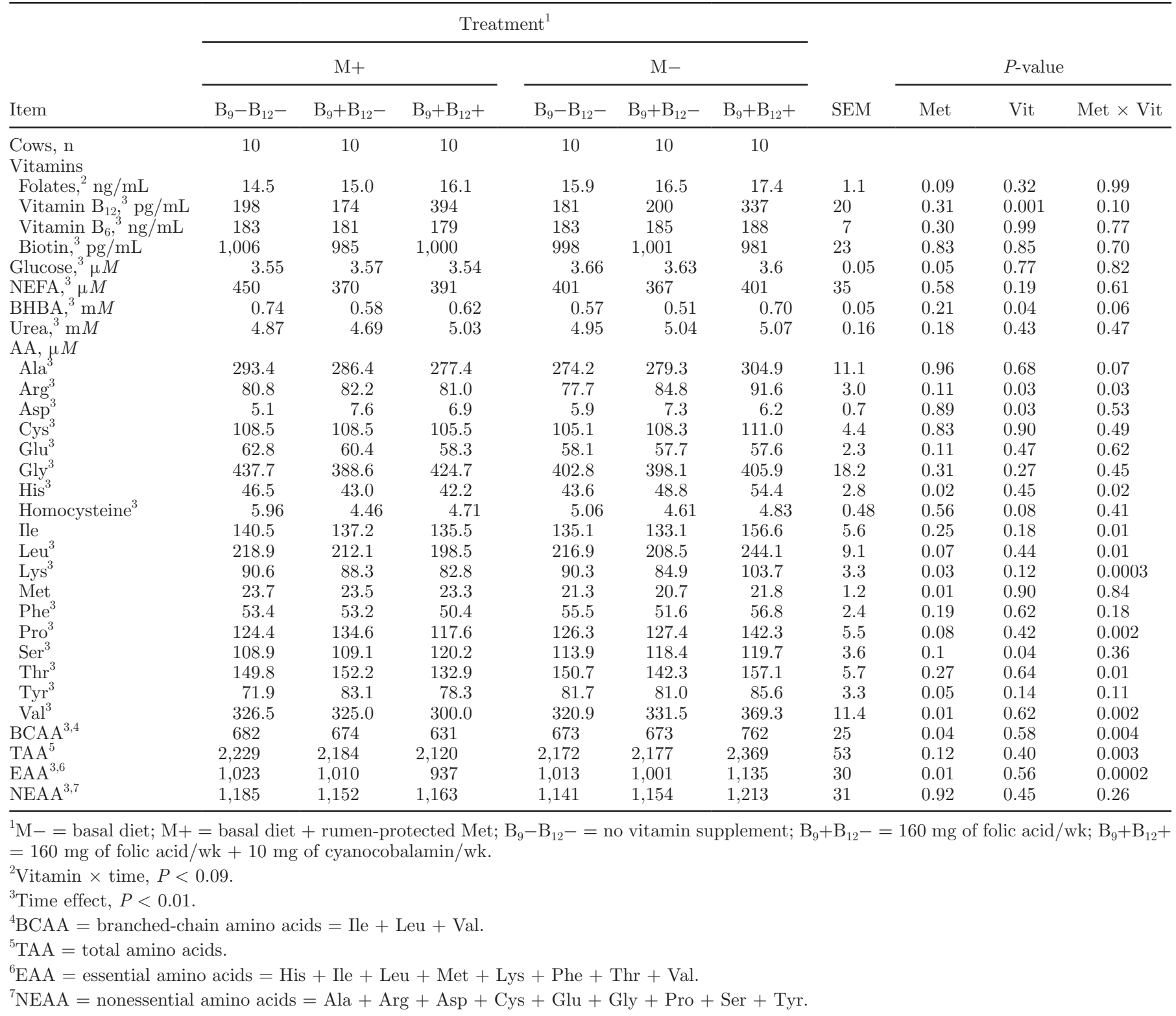




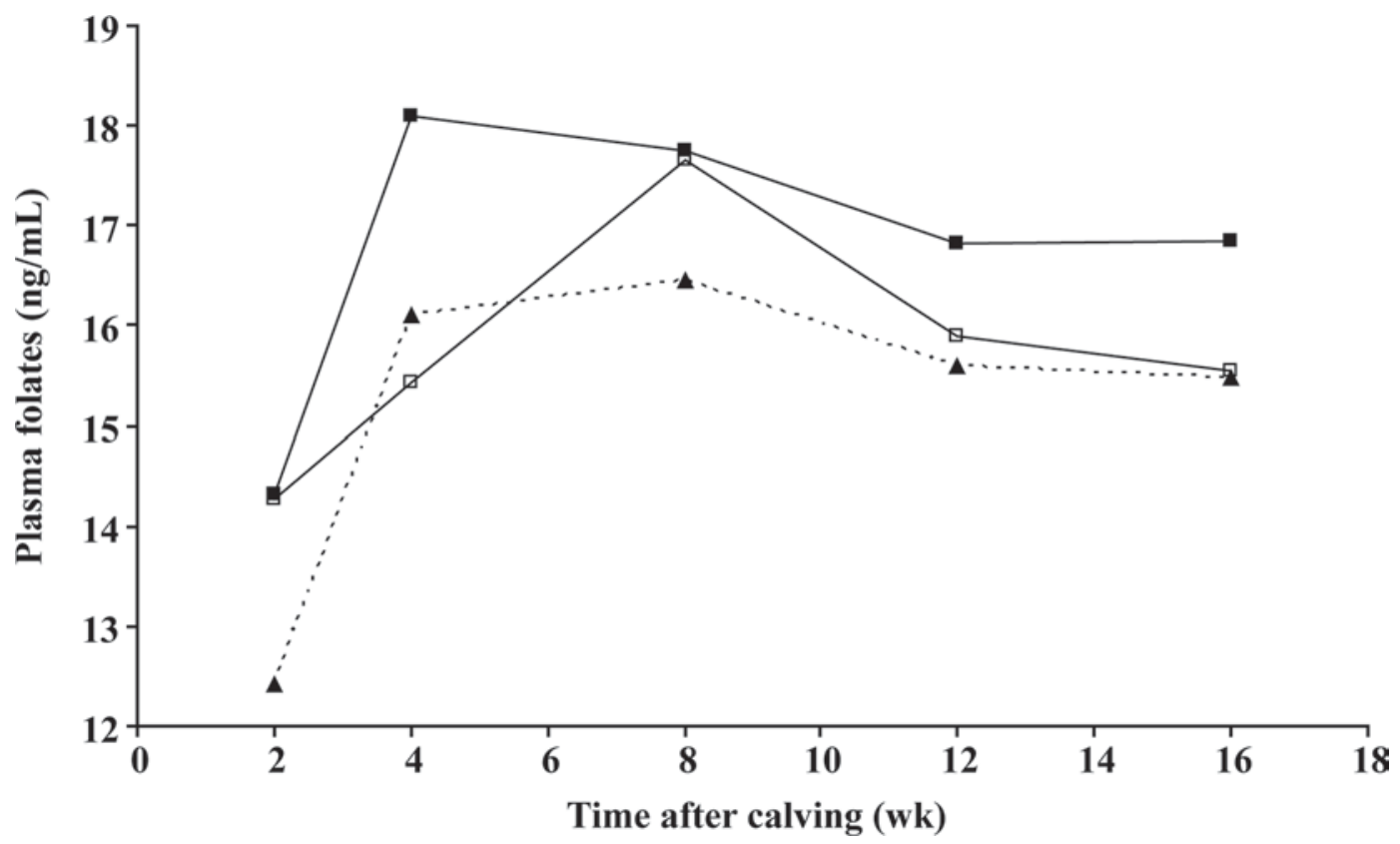

Figure 3. Effects of intramuscular injections of folic acid $\left(\mathrm{B}_{9}\right)$ and vitamin $\mathrm{B}_{12}\left(\mathrm{~B}_{12}\right)$ given to dairy cows from 3 wk before calving to 16 wk of lactation on plasma concentrations of folates. Values are averages of the 2 levels of Met supply. $\mathrm{B}_{9}-\mathrm{B}_{12}-\left(-\mathbf{\Lambda}^{--}\right)=$no vitamin supplement; $\mathrm{B}_{9}+\mathrm{B}_{12}-(-\square-)=160 \mathrm{mg}$ of folic acid/wk; $\mathrm{B}_{9}+\mathrm{B}_{12}+(-\square)=160 \mathrm{mg}$ of folic acid/wk $+10 \mathrm{mg}$ of vitamin $\mathrm{B}_{12} /$ wk $(\mathrm{SEM}=1.0 ;$ vitamin $\times$ time interaction, $P=0.03)$.

Plasma concentrations of urea were not different among treatments $(P \geq 0.2$; Table 3$)$ but increased throughout the experimental period (time, $P=0.001$ ), $3.8,4.6,5.0,5.7$, and $5.8 \pm 0.1 \mathrm{mM}$, at $2,4,8,12$, and 16 wk of lactation, respectively.

$\boldsymbol{A} \boldsymbol{A}$. Dietary supplements of RPM increased plasma concentrations of Met from 21 to $24 \pm 1 \mu M(P=0.01)$ but decreased plasma concentrations of Tyr $(P=0.05$; Table 3$)$ and Ser $(P=0.10$; Table 3$)$.

Plasma concentrations of Ser $(P=0.04)$, Asp $(P=$ $0.03)$, and Hcy $(P=0.08)$ changed according to vitamin supplementation (Table 3 ). Folic acid and vitamin $\mathrm{B}_{12}$ given together tended to increase plasma concentrations of Ser compared with the other 2 treatments $(P \leq 0.07): 111,114$, and $120 \pm 3 \mu M$ for $\mathrm{B}_{9}-\mathrm{B}_{12}-$, $\mathrm{B}_{9}+\mathrm{B}_{12}-$, and $\mathrm{B}_{9}+\mathrm{B}_{12}+$, respectively. Plasma Asp was higher $(P=0.02)$ in $\mathrm{B}_{9}+\mathrm{B}_{12}-(7.4 \pm 0.5 \mu M)$ than in $\mathrm{B}_{9}-\mathrm{B}_{12}-(5.5 \pm 0.5 \mu M)$ but was not different $(P=$ $0.6)$ from $\mathrm{B}_{9}+\mathrm{B}_{12}+$ cows $(6.6 \pm 0.5 \mu M)$. Intramuscular injections of folic acid alone $(P=0.03)$ or combined with vitamin $\mathrm{B}_{12}(P=0.09)$ tended to decrease plasma concentrations of $\mathrm{Hcy}$, from 5.51 to 4.54 and $4.77 \pm$ $0.37 \mu M$ in $\mathrm{B}_{9}-\mathrm{B}_{12}-, \mathrm{B}_{9}+\mathrm{B}_{12}-$, and $\mathrm{B}_{9}+\mathrm{B}_{12}+$ cows, respectively $(P=0.08$; Table 3$)$.

The responses of plasma concentrations of Ala, Arg, His, Ile, Leu, Lys, Pro, Val, branched-chain AA, essential AA, and total AA to vitamin injections differed according to the level of Met supplementation (Met $\times$ vitamin interaction, $P \leq 0.07$; Table 3$)$. In $\mathrm{M}-$ cows, plasma concentrations of these AA were higher $(P \leq$ $0.04)$ in $\mathrm{B}_{9}+\mathrm{B}_{12}+$ cows compared with cows on the other treatments, whereas the vitamin supplements had no such effect in $\mathrm{M}+$ cows $(P \geq 0.05)$. An opposite trend was observed for plasma Thr (Met $\times$ vitamin interaction, $P \leq 0.01$ ).

Globally, plasma concentrations of Ala, Arg, Cys, His, Hcy, Leu, Lys, Phe, Pro, Ser, Val, branched-chain $\mathrm{AA}$, and essential AA increased throughout the experimental period toward a plateau at the end of the experimental period (time, $P \leq 0.002$, data not shown). Plasma concentrations of Asp, Thr, and Tyr increased from 2 to $8 \mathrm{wk}$ of lactation but decreased thereafter (time, $P \leq 0.01$ ). Plasma Gly, Glu, and nonessential AA decreased as the lactation progressed (time, $P \leq$ $0.001)$, whereas there was no effect of time $(P \geq 0.12)$ on plasma Ile, Met, and total AA.

\section{DISCUSSION}

Based on changes in milk and plasma concentrations of vitamin $\mathrm{B}_{12}$, intramuscular injections of vitamin $\mathrm{B}_{12}$ increased the supply of this vitamin to dairy cows as observed by Girard and Matte (2005b). However, the increase in plasma vitamin $\mathrm{B}_{12}$ was smaller in $\mathrm{M}-$ cows than in $\mathrm{M}+$ cows, suggesting a difference in tissue utilization of the vitamin according to Met supply. 
Milk concentrations of folates were not affected by folic acid injections although the amount of folates secreted in milk daily was higher in $\mathrm{B}_{9}+\mathrm{B}_{12}+$ cows. The absence of response of plasma concentrations of folates, determined $7 \mathrm{~d}$ after the weekly intramuscular injections of folic acid, could be due to the rapid plasma clearance of folic acid after intramuscular injections of this vitamin (Girard et al., 1989). Similarly, regardless of parity, a single intramuscular injection of folic acid failed to increase plasma and milk concentrations of folates in early lactation (Girard et al., 1989). However, weekly intramuscular injections of $160 \mathrm{mg}$ of folic acid given for at least $30 \mathrm{wk}$ before calving increased plasma folates from 14 to $17 \mathrm{ng} / \mathrm{mL}$ during the first 6 wk of lactation but had no effect on milk concentrations of folates (Girard et al., 1995). Nevertheless, independent of vitamin supply, plasma folates decreased when Met supply increased as also reported in rat (Gawthorne and Stokstad, 1971; Thenen and Stokstad, 1973) and human (Connor et al., 1978). This is probably due to SAM intracellular concentrations rising in parallel to Met supply and acting as an allosteric inhibitor of methylenetetrahydrofolate reductase (MTHFR; Lucock, 2000). The latter is the enzyme promoting the conversion of 5,10-methylene-THF to 5-methyl-THF, the major form of folates in human (Selhub, 1999) and cow (C. L. Girard; unpublished data) plasma.

In the present experiment, supplementary folic acid alone had no effect on milk production or milk component yields of multiparous cows but in $\mathrm{M}+$ cows, it decreased gross efficiency, calculated as milk yield/DMI. Supplementation of folic acid plus vitamin $\mathrm{B}_{12}$ tended to increase milk production and milk component yields (CP, lactose, and total solids), the effect being greater during the first $4 \mathrm{wk}$ of lactation. Indeed, the effects of supplementary folic acid on lactational performance of dairy cows reported in the literature are variable. In early lactation, milk production was either unchanged or depressed following folic acid supplementation in primiparous cows, whereas in cows at their second or greater lactation, milk production was increased (Girard et al., 1995; Girard and Matte, 1998). However, Girard et al. (2005) observed no effect of folic acid supplements on milk and milk component yields in multiparous cows fed a basal diet supplemented or not with Met. Nevertheless, intramuscular injections of vitamin $\mathrm{B}_{12}$ improved milk and milk component yields of primiparous cows fed the same basal diet as the one fed in the study of Girard et al. (2005) supplemented with RPM and folic acid (Girard and Matte, 2005b). Graulet et al. (2007) observed that dietary supplements of folic acid, given alone or combined with vitamin $\mathrm{B}_{12}$, increased milk and milk protein yields to the same extent, whereas feeding the 2 vitamins together increased metabolic efficiency.
However, in that study, supplementary vitamin $\mathrm{B}_{12}$ alone had no effect on lactational performance.

Even if milk component yields tended to be increased by the combined supplement of folic acid and vitamin $\mathrm{B}_{12}$ without increasing DMI, especially in early lactation, there was no increment in plasma concentrations of NEFA and BHBA, indicating a possible improvement in metabolic efficiency when folic acid and vitamin $B_{12}$ were given together. These observations are supported by the results from a study conducted on a subgroup of cows from the present experiment in which whole-body glucose and Met fluxes were measured at 12 wk of lactation (Preynat et al., 2009). In the latter study, supplementary folic acid and vitamin $\mathrm{B}_{12}$ given together increased glucose whole-body flux, probably because of an increase in gluconeogenesis. Along the same lines, Graulet et al. (2007) observed that, even if milk production was similar for cows fed supplementary folic acid alone or combined with vitamin $\mathrm{B}_{12}$, plasma concentration of glucose was higher in cows fed the 2 vitamins together. Vitamin $\mathrm{B}_{12}$ is a coenzyme for methylmalonylCoA mutase, a mitochondrial enzyme essential to the entry of propionate in the Krebs cycle, propionate being the major glucose precursor in ruminants (Kennedy et al., 1990; Taoka et al., 1994). However, even if folates are not known to participate in the methylmalonylCoA pathway, Graulet et al. (2007) reported that the affinity of the enzyme for vitamin $\mathrm{B}_{12}$ was increased in the liver of cows fed folic acid and vitamin $\mathrm{B}_{12}$ together compared with no vitamin supplements or the 2 vitamins given separately. Similarly, Selhub et al. (2007) observed that both metabolic pathways involving the vitamin $\mathrm{B}_{12}$-dependent enzymes methionine synthase and methylmalonylCoA mutase are affected by folic acid supply. According to these authors, when vitamin $\mathrm{B}_{12}$ supply is adequate, increasing folate status improves the efficiency of the 2 vitamin $\mathrm{B}_{12}$-dependent enzymes, whereas when vitamin $\mathrm{B}_{12}$ status is low, increasing folate supply worsens the 2 enzymatic functions. Such an effect needs to be further investigated.

Biotin, another B vitamin, is a coenzyme for the enzyme propionyl-CoA carboxylase, which is involved in the reaction preceding the action of methylmalonylCoA mutase in the metabolic pathway for the entry of propionate in the Krebs cycle (Combs, 1998). In the present experiment, plasma concentrations of biotin were not affected by treatments giving an indication that, even if efficiency of this metabolic pathway was improved by vitamin supplements, biotin supply did not seem to be limiting.

Plasma concentrations of Hcy were decreased by injections of folic acid, alone or combined with vitamin $\mathrm{B}_{12}$, independently of Met supply. Within cells, 
especially hepatic cells, the metabolic fates of Hcy are catabolism through the transsulfuration pathway or remethylation. In the latter pathway, Hcy accepts a methyl group from 5-methyl-THF to form Met via a vitamin $\mathrm{B}_{12}$-dependent enzyme, methionine synthase (Selhub, 1999). Excess of Hcy is exported out of the cells to maintain low intracellular concentrations of this cytotoxic AA (Selhub, 1999), explaining the small concentrations of Hcy normally present in plasma. As observed in humans (Mangum et al., 1969; Stam et al., 2005), supplements of folic acid, with or without vitamin $\mathrm{B}_{12}$, probably reduced plasma concentrations of Hcy through an enhancement of methionine synthase activity. The effect of treatments on the transsulfuration pathway was limited as they had no effect on plasma concentrations of Cys or vitamin $\mathrm{B}_{6}$, a coenzyme for 2 enzymes of this pathway.

The RPM supplement used in the present experiment increased plasma concentrations of Met as previously reported (Overton et al., 1996, 1998). It also increased $\mathrm{CP}$ concentrations in milk, which is the effect the most frequently reported in the literature (NRC, 2001; Leonardi et al., 2003; Socha et al., 2005) but had no effect on milk CP yield. Although in the current experiment, feeding RPM slightly decreased glucose concentrations by $2 \%$ and tended to increase plasma concentrations of BHBA by $30 \%$ in cows fed no vitamin supplement, glucose concentrations were within the normal physiological range (Ohgi et al., 2005) and BHBA concentrations were below the limit for ketosis (1 $\mathrm{m} M$; Gröhn et al., 1983). These observations are consistent with a slight increase in body reserve mobilization in cows fed RPM based on an average loss of $14 \mathrm{~kg}$ of BW between wk 2 and 4 of lactation.

The effects of vitamin supplements on milk component yields did not differ according to Met supply. However, intramuscular injections of the 2 vitamins together increased plasma concentrations of Ala, Arg, His, Ile, Leu, Lys, Val, branched-chain AA, total AA, and essential AA in $\mathrm{M}-$ cows, whereas there was no such effect in $\mathrm{M}+$ cows. This observation suggests a change in whole-body protein metabolism with folic acid and vitamin $B_{12}$ injections when Met supply was low. In a subgroup of cows from the present experiment, it was observed that the combined supplement of folic acid and vitamin $B_{12}$ increased protein synthesis through increased protein turnover when Met supply was low and through decreased Met oxidation when RPM was fed (Preynat et al., 2009).

\section{CONCLUSIONS}

In the present experiment, the effects of RPM on plasma folates as well as differences in response to RPM of plasma concentrations of vitamin $\mathrm{B}_{12}$ and several AA according to vitamin supplements suggest that Met supply affected tissue utilization of these vitamins and whole-body protein metabolism. However, despite the observation that plasma Hcy was decreased by supplementary folic acid, alone or combined with vitamin $\mathrm{B}_{12}$, folic acid supplements alone had no positive effect on milk and milk component yields. Moreover, because supplying preformed labile methyl groups as RPM had no effect on milk or milk component yields, it is unlikely that the effect of the combined supplement of vitamins on lactational performance during the first weeks of lactation, when plasma concentrations of vitamin $\mathrm{B}_{12}$ were the lowest, were due to an improvement in methyl group supply through methylneogenesis. Nevertheless, folic acid and vitamin $B_{12}$ given together increased milk and milk component yields during the first weeks of lactation without an effect on DMI or plasma NEFA. Given the experimental design used, it is not, however, possible to conclude if these effects were due to the combination of the 2 vitamins or to vitamin $B_{12}$ itself.

\section{ACKNOWLEDGMENTS}

The authors are grateful to Guylaine Fortin, Michel Poitras, and Jean Vallières for animal care, to Chrystiane Plante, Véronique Roy, and Linda Marier of Agriculture et Agroalimentaire Canada, Sherbrooke, and Micheline Gingras of Universite Laval, Quebec, for technical assistance, and to Steve Méthot of Agriculture et Agroalimentaire Canada, Sherbrooke, for statistical advice. Thanks are also extended to the financial support of the Action Concertée Fonds NOVALAIT Inc.- FQRNT-MAPAQ-Agriculture et Agroalimentaire Canada.

\section{REFERENCES}

Agriculture Canada. 1990. Recommended Code of Practice for Care and Handling of Dairy Cattle. Publ. No. 1853/E. Agriculture Canada, Ottawa, Ontario, Canada.

Association of Official Analytical Chemists. 1990. Official Methods of Analysis. 15th ed. AOAC, Arlington, VA.

Bässler, K. H. 1997. Enzymatic effects of folic acid and vitamin $B_{12}$. Int. J. Vitam. Nutr. Res. 67:385-388.

Berthiaume, R., P. Dubreuil, M. Stevenson, B. W. McBride, and H. Lapierre. 2001. Intestinal disappearance and mesenteric and portal appearance of amino acids in dairy cows fed ruminally protected methionine. J. Dairy Sci. 84:194-203.

Canadian Council on Animal Care. 1993. Guide to the Care and Use of Experimental Animals. 2nd ed. Vol. 1. E. D. Rolfert, B. M. Cross, and A. A. McWilliam, ed. Can. Counc. Anim. Care, Ottawa, Ontario, Canada.

Combs, G. F., Jr. 1998. The vitamins. Fundamental Aspects in Nutrition and Health. 2nd ed. Academic Press, San Diego, CA.

Connor, H., D. J. Newton, F. E. Preston, and H. F. Woods. 1978. Oral methionine loading as a cause of acute serum folate deficiency: Its relevance to parenteral nutrition. Postgrad. Med. 54:318-320.

Gawthorne, J. M., and E. L. R. Stokstad. 1971. The effect of vitamin $\mathrm{B}_{12}$ and methionine on folic acid uptake by rat liver. Proc. Soc. Exp. Biol. Med. 136:42-46. 
Girard, C. L., H. Lapierre, J. J. Matte, and G. E. Lobley. 2005. Effects of dietary supplements of folic acid and rumen-protected methionine on lactational performance and folate metabolism of dairy cows. J. Dairy Sci. 88:660-670.

Girard, C. L., and J. J. Matte. 1988. Blood serum concentrations of folates and vitamin $B_{12}$ during growth period of white veal calves. Can. J. Anim. Sci. 68:455-460.

Girard, C. L., and J. J. Matte. 1998. Dietary supplements of folic acid during lactation: effects on the performance of dairy cows. J. Dairy Sci. 81:1412-1419.

Girard, C. L., and J. J. Matte. 2005a. Folic acid and vitamin $\mathrm{B}_{12}$ requirements of dairy cows: a concept to be revised. Livest. Prod. Sci. 98:123-133.

Girard, C. L., and J. J. Matte. 2005b. Effects of intramuscular injections of vitamin $\mathrm{B}_{12}$ on lactation performance of dairy cows fed dietary supplements of folic acid and rumen-protected methionine. J. Dairy Sci. 88:671-676.

Girard, C. L., J. J. Matte, and G. F. Tremblay. 1989. Serum folates in gestating and lactating dairy cows. J. Dairy Sci. 72:3240-3246.

Girard, C. L., J. J. Matte, and G. F. Tremblay. 1995. Gestation and lactation of dairy cows: a role for folic acid? J. Dairy Sci. 78:404411.

Graulet, B., J. J. Matte, A. Desrochers, L. Doepel, M. F. Palin, and C. L. Girard. 2007. Effects of dietary supplements of folic acid and vitamin $\mathrm{B}_{12}$ on metabolism of dairy cows in early lactation. J. Dairy Sci. 90:3442-3455

Gröhn, Y., L. A. Lindberg, M. L. Bruss, and T. B. Farver. 1983. Fatty infiltration of liver in spontaneously ketotic dairy cows. J. Dairy Sci. 66:2320-2328.

Kennedy, D. G., A. Cannavan, A. Molloy, F. O'Harte, S. M. Taylor, S. Kennedy, and W. J. Blanchflower. 1990. MethylmalonylCoA mutase (EC 5.4.99.2) and methionine synthetase (EC 2.1.1.13) in the tissues of cobalt-vitamin $\mathrm{B}_{12}$ deficient sheep. Br. J. Nutr. 64:721-732.

Leonardi, C., M. Stevenson, and L. E. Armentano. 2003. Effect of two levels of crude protein and methionine supplementation on performance of dairy cows. 2003. J. Dairy Sci. 86:4033-4042.

Lucock, M. 2000. Folic acid: Nutritional biochemistry, molecular biology, and role in disease processes. Mol. Genet. Metab. 71:121138.

Malinow, M. R., S. S. Kang, L. M. Taylor, P. W. K. Wong, B. Coull, T. Inahara, D. Mukerjee, G. Sexton, and B. Upson. 1989. Prevalence of hyperhomocyst(e)inemia in patients with peripheral arterial occlusive disease. Circulation 79:1180-1188.

Mangum, J. H., B. K. Murray, and J. A. North. 1969. Vitamin B dependent methionine biosynthesis in cultured mammalian cells. Biochemistry 8:3496-3499.

Matte, J. J., A. A. Ponter, and B. Sève. 1997. Effects of chronic parenteral of pyridoxine and acute enteric tryptophan on pyridoxine status, glycemia and insulinemia stimulated by enteric glucose in weanling piglets. Can. J. Anim. Sci. 77:663-668.

NRC. 2001. Nutrient Requirements of Dairy Cattle. 7th rev. ed. Natl. Acad. Press, Washington, DC.
Ohgi, T., S. Kamimura, Y. Minezaki, and M. Takahashi. 2005. Relationship between fat accumulation in the liver and energy intake, milk fat yield and blood metabolites in dairy cows. Anim. Sci. 76:549-557.

Overton, T. R., L. S. Emmert, and J. H. Clark. 1998. Effects of source of carbohydrate and protein and rumen-protected methionine on performance of cows. J. Dairy Sci. 81:221-228.

Overton, T. R., D. W. LaCount, T. M. Cicela, and J. H. Clark. 1996. Evaluation of a ruminally protected methionine products for lactating dairy cows. J. Dairy Sci. 79:631-638.

Petidier, A. S. Rubio, A. Gomez-Hens, and M. Valcarcel. 1986. Simultaneous and direct determination of pyridoxal, pyridoxal5 '-phosphate, pyridoxic acid in serum by derivative synchronous fluorescence spectroscopy. Anal. Biochem. 157:212-220.

Preynat, A., H. Lapierre, C. M. Thivierge, M. F. Palin, J. J. Matte, A. Desrochers, and C. L. Girard. 2009. Effects of supplements of folic acid, vitamin $\mathrm{B}_{12}$ and rumen-protected methionine on whole body metabolism of methionine and glucose in lactating dairy cows. J. Dairy Sci. 92:677-689.

Santschi, D. E., J. Chiquette, R. Berthiaume, R. Martineau, J. J. Matte, A. F. Mustafa, and C. L. Girard. 2005. Effects of the forage to concentrate ratio on B-vitamin concentrations in different ruminal fractions of dairy cows. Can. J. Anim. Sci. 85:389-399.

SAS Institute. 2004. SAS/STAT User's Guide: Volumes 1-7. SAS Inst. Inc., Cary, NC.

Scott, J. M., and D. G. Weir. 1981. The methyl trap. A physiological response in man to prevent methyl group deficiency in kwashiorkor (methionine deficiency) and an explanation for folic-acid induced exacerbation of subacute combined degeneration in pernicious anaemia. Lancet 2:337-340.

Selhub, J. 1999. Homocysteine metabolism. Annu. Rev. Nutr. 19:217246

Selhub, J., M. S. Morris, and P. F. Jacques. 2007. In vitamin $B_{12}$ deficiency, higher serum folate is associated with increased total homocysteine and methylmalonic acid concentrations. Proc. Natl. Acad. Sci. USA 104:19995-20000.

Socha, M. T., D. E. Putnam, B. D. Garthwaite, N. L. Whitehouse, N. A. Kierstead, C. G. Schwab, G. A. Ducharme, and J. C. Robert. 2005. Improving intestinal amino acid supply of pre- and postpartum dairy cows with rumen-protected methionine and lysine. J. Dairy Sci. 88:1113-1128.

Srivastava, S. K., and E. Beutler. 1973. A new fluorimetric method for the determination of pyridoxal 5'-phosphate. Biochim. Biophys. Acta 304:765-773.

Stam, F., Y. M. Smulders, C. Guldener, C. Jakoks, C. D. A. Stehouwer, and K. Meer. 2005. Folic acid treatment increases homocysteine remethylation and methionine transmethylation in healthy subjects. Clin. Sci. 108:449-456.

Taoka, S., R. Padmakumar, M. Lai, H. Liu, and R. Banerjee. 1994. Inhibition of the human methylmalonyl-CoA mutase by various Co-A esters. J. Biol. Chem. 269:31630-31634.

Thenen, S. W., and E. L. R. Stokstad. 1973. Effect of methionine on specific folate coenzyme pools in vitamin $\mathrm{B}_{12}$ deficiency and supplemented rats. J. Nutr. 103:353-370. 